\title{
Finsk kasus i dansk sprogforskning. Fra Rask til Hjelmslev og Ohrt
}

\author{
Viggo Bank Jensen
}

\begin{abstract}
In this paper, inspired by research in the Hjelmslev Archive, I examine how three Danish scholars have approached the Finnish case system. It is demonstrated (1) that Rasmus Rask (1787-1832) historically had an important role in the systematization and denomination of the Finnish cases; (2) that Rask's schematic systematization plays an important role for the case theory published in 1935 by Louis Hjelmslev (1899-1965); (3) and that Hjelmslev's rendering of Rask's case diagram causes some criticism from his former teacher of Finnish, Ferdinand Ohrt (1873-1978).
\end{abstract}

\section{Nøgleord}

det finske kasussystem, Rasmus Rask, Ferdinand Ohrt, Louis Hjelmslev

\section{Indledning}

I denne artikel vil jeg opridse en linje i diskussionen i dansk sprogforskning vedrørende det finske kasussystem, fra Rasmus Rask (1787-1832) til Ferdinand Ohrt (1873-1938) og Louis Hjelmslev (1899-1965). Min interesse for emnet er opstået under min forskning i Hjelmslevs arkiver i forbindelse med det treårige projekt "Infrastrukturalisme", der skal føre til en digitaliseret, kommenteret udgave af centrale dele af Hjelmslevs korrespondance og upublicerede manuskripter. Mine søgninger i arkiverne har vist at finsk for Hjelmslev var et meget centralt sprog, både vedrørende hans egne studier, hans udgave af Rask og hans arbejde med studieordninger. Hjelmslev har imidlertid aldrig publiceret en selvstændig artikel eller bog om finsk, og derfor er denne interesse forblevet lidt upåagtet.

Det konkrete udgangspunkt for artiklen er et brev til Hjelmslev (6. marts 
1937) ${ }^{1}$ fra hans gamle finsklærer fra universitetet, folkloristen Ferdinand Ohrt, som bl.a. skriver: "at jeg ikke ret kan forstaa Deres finske KasusSkema - hvilket jeg ogsaa meddelte Professor Jespersen, der sendte mig sin Bog "Analytic Syntax", hvor Deres Skema staar p. 116." Ifølge Ohrt selv kender han kun Hjelmslevs fremstilling af finsk kasus via Jespersen (1937). Hjelmslev svarer (24.april) og skriver:

[...] jeg læste Deres brev med stigende undren og rædsel, indtil det gik op for mig, at Jespersens noget uheldige (for mig altsaa saare uheldige) formulering har faaet Dem til at tro, at jeg accepterer dette af Rasmus Rask opstillede kasussystem for finsk. Jeg behandler i min bog Rasks system i mit historiske afsnit og betragter det dær som et afgörende historisk fremskridt, hvilket De sikkert vil være enig med mig i, hvis De kender og husker hans forgængeres kasus-teorier og -navne ( $\mathrm{fx}$... Vhael ...), men aldeles ikke som definitivt, tværtimod siger jeg: Il va de soi que dans le détail le système établi par Rask peut être sujet à discussion. ${ }^{2}$

Selv om Hjelmslev (1935) i sin kasusbog kun behandler Rasks finske kasussystem i tre kortere sekvenser, spiller dette system dog en mere central rolle i Hjelmslevs bog end svaret til Ohrt lægger op til. I de følgende to hovedafsnit behandles følgende forhold: (1) Hvad ligger der i at Hjelmslev i svarbrevet til Ohrt skriver at det "af Rasmus Rask opstillede kasussystem for finsk ... er et afgörende historisk fremskridt" i forhold til Vhael? (2) Hvordan gengiver Hjelmslev Rasks kasussystem i La catégorie des cas 1 (Hjelmslev 1935)? Hvilken rolle spiller Rask og finsk kasus i dette værk? Er Ohrts kritik berettiget?

\section{Fra Vhael til Rask}

\subsection{Rask ogfinsk grammatik. Mødet med Gustaf Renvall, 1818}

Finsk blev etableret som litteratursprog mellem 1550 og 1650 især via bibeloversættelser samt etablering af et akademi i Åbo (Turku på finsk). Den

1 Hjelmslev-Arkivet, kps.97.

2 "Det siger sig selv at det af Rask opstillede system kan diskuteres vedrørende detaljerne" (HjelmslevArkivet, kps.97). 
første finske grammatik der for alvor slog igennem, var Vhaels grammatik fra 1733, der var skrevet på latin. Christfrid Ganander (1741-1790) havde udarbejdet et omfattende manuskript til en større finsk ordbog, men det lå imidlertid hengemt i universitetsbibliotekets håndskriftsamling i Åbo.

Rasmus Rask havde sat sig ind i finsk allerede inden udgivelsen af sit hovedværk (Rask (1818), men skrevet omkring 1814) hvor der også er et længere afsnit om finsk, i hvilket Rask nævner Vhaels grammatik. Fra 1816 til 1823 var Rask på sin store udlandsrejse, herunder både i Finland og St. Petersborg. Han var i Finland fra 27. feb. til 27. marts 1818, herunder 18 dage i Åbo, hvor han i 14 dage hver aften fik intensiv undervisning i finsk af universitetsadjunkt Gustaf Renvall (1781-1841). Renvall havde allerede 1815-1817 udgivet en tekst om finsk kasus og var nu i færd med at skrive en samlet grammatik (Renvall 1840). Rask blev undervist via Lukasevangeliet, Vhaels grammatik samt det foreløbige manuskript til Renvalls grammatik.

Renvall havde selv, men forgæves, søgt at skaffe midler til at udgive en ordbog på basis af Gananders manuskript. Rask skaffede derimod penge til projektet via sin kontakt til den indflydelsesrige grev Rumjantsev i St. Petersborg. Efter at Rask var taget af sted fra Åbo, fulgte en længere korrespondance med Renvall, hvoraf hovedsagelig Renvalls breve er bevaret.

\subsection{Nogle opstillinger af finsk kasus 1733-1840, herunder Rasks}

\subsubsection{Vhaels kasusfremstilling}

Bartholdus G. Vhaels fremstilling i Grammatica Fennica (1733) var et vendepunkt og var dominerende i fremstillingen af det finske kasussystem de efterfølgende knap 100 år.

Vhael opstiller 14 kasus. Hans definitioner eller forklaringer vedrørende de forskellige kasus' betydning fremgår af en oversigt hvor han med ordet fisk som eksempel oversætter de forskellige kasusformer til latin og svensk, som det fremgår af nedenstående oversigt. I højre kolonne er de nu gængse kasusbetegnelser for de viste former. Nummereringen er Vhaels. Jeg har gjort Vhaels finske ortografi mere moderne: ${ }^{3}$

3 Gængse betegnelser, se fx F. Karlsson (2000: 28, 133). Her nævnes yderligere akkusativ, samt 'komitativ', en sjældent optrædende kasus. 


\begin{tabular}{|c|c|c|}
\hline $\begin{array}{l}\text { Vhaels } \\
\text { kasusbetegnelser }\end{array}$ & $\begin{array}{l}\text { Vhaels eksempel på form, samt 'forklaring' af } \\
\text { brug via oversættelse til latin og svensk }\end{array}$ & $\begin{array}{l}\text { Gængse } \\
\text { betegnelser i dag }\end{array}$ \\
\hline 1. Nominativus & kala / piscis, fisk & Nominativ \\
\hline 2. Genitivus & kalan / piscis, fiskens & Genitiv \\
\hline 3. Dativus & kalalle / pisci, åth fisken [til fisken] & Allativ \\
\hline 4. Accusativus & kalaa / piscem, fisken & Partitiv \\
\hline 5. Vocativus & kala / piscis, fisk & - \\
\hline 6. Ablativus & $\begin{array}{l}\text { kalasta / de / ex pisce, om / och ti [ut ur] fisken } \\
\text { (tilføjelsen bygger på en note af Rask der } \\
\text { relevant justerer Vhael (jf. tabel } 3 \text { i } 2.2 .2 \text {.) }\end{array}$ & Elativ \\
\hline 7. Locativus & kalassa / in pisce, uti fisken & Inessiv \\
\hline $\begin{array}{l}\text { 8. Mediativus / } \\
\text { Organicus }\end{array}$ & kalalla / cum pisce, med fisken & Adessiv \\
\hline 9. Privativus & kalalta / a pisce, utaf fisken & Ablativ \\
\hline 10. Negativus & kalatta / sine pisce, utan fisk & Abessiv \\
\hline 11. Factivus/Mutativus & kalaksi / mutatus in piscem, blef til fisk & Translativ \\
\hline 12. Nuncupativus & $\begin{array}{l}\text { kalana; kalana kulki / perrexit instar piscis, han } \\
\text { fór såsom en fisk }\end{array}$ & Essiv \\
\hline 13. Penetrativus & kalaan / in piscem, inn i fisken & Illativ \\
\hline $\begin{array}{l}\text { 14. Instructivus / } \\
\text { Descriptivus }\end{array}$ & $\begin{array}{l}\text { kaloin / fiskevijs. [af varas 'tyv'] varkain / } \\
\text { instar furis, furtim, såsom en tiuf / stiålandes [i } \\
\text { smug] }\end{array}$ & Instruktiv \\
\hline
\end{tabular}

Rækkefølgen viser at Vhael stadig er stærkt påvirket af det latinske system. Han vælger som de første seks at bringe de former der har betegnelser fra den latinske grammatik, han "indfører" også en vokativ i finsk selv om der ikke er nogen selvstændig form der berettiger til det. Den konkrete form som Vhael i sin opstilling kalder 'akkusativ', kaldes i dag normalt partitiv, mens akkusativ ikke knyttes entydigt til en bestemt form, men bruges om den syntaktiske brug af tre forskellige former, nemlig nominativ, genitiv og partitiv. ${ }^{4}$ I den kommenterende tekst redegør Vhael delvist for disse forhold. Bortset fra disse småjusteringer dækker Vhaels 13 kasus (ud over vokativ) nogenlunde de kasusformer der optræder i gængse grammatikfremstillinger i dag, men Vhaels navngivning og systematik svarer ikke til nyere fremstillinger.

\subsubsection{Ekskurs: Akkusativ - et omdiskuteret emne i finsk grammatik + lidt om translativ} I finsk regnes ofte med ca. 15 kasus, jf. højre kolonne i tabel 1 inkl. note 3 om komitativ. Et særligt problem er akkusativs rolle. I rekonstrueret uralsk, forgængeren for finsk, regner forskerne med en akkusativ-singularisform

4 Se ekskurs i 2.2.2. og vedrørende pronominer også 3.5. 
på -m. På finsk falder den på et tidspunkt sammen med genitiv-singularis på $-n$. Partitivformen der vurderes oprindeligt at være en separativ-kasus, får et meget bredere anvendelsesområde og indgår blandt andet som kasus for direkte objekt i forskellige sammenhænge. I finsk har der nu i flere århundreder ikke været noget specifikt akkusativmærke når det gælder substantiver (og adjektiver).

Direkte objekt udtrykkes med partitiv i bl.a. nægtelsessætninger, ved ikkeresultative handlinger og ved ubestemte mængder af objektet $(1)^{5}$. Direkte objekt udtrykkes med nominativendelser $(-t)$ i pluralis, bl.a. ved helhed/ bestemte mængder og ved resultativ handling, samt som $(\varnothing)$ i singularis, fx ved bydemåde (1., 2. person) og passiv. Genitivendelsen bruges til at udtrykke direkte objekt i singularis ved helhed/bestemte mængder og ved resultativ handling (2). En særlig problematik er brug af - $t$ ved pronominer som direkte objekt, fx häne-t $(=$ hende/ham) (3) til forskel fra nominativformen (Ø-endelse): hän (=hun/han) (F. Karlsson: 2000: $111 \mathrm{ff}$ ):

$$
\begin{array}{ll}
\text { löys-i-n } & \text { sokeri-a } \\
\text { finde-PRÆT-1SG } & \text { sukker-PARTITIV } \\
\text { 'jeg fandt } & \text { (noget) sukker' }
\end{array}
$$

$$
\begin{array}{ll}
\text { löys-i-n } & \text { tytö-n } \\
\text { finde-PRÆT-1sG } & \text { pige-GENITIV } \\
\text { 'jeg fandt } & \text { pigen' }
\end{array}
$$

$\begin{array}{ll}\text { löys-i-n } & \text { häne-t } \\ \text { finde-PRÆT-1SG } & \text { hun-AKKUSATIV } \\ \text { 'jeg fandt } & \text { hende' }\end{array}$

Vhael (1733) har i sin opstilling en akkusativkasus, men deler den i to: partialis (partitiv) og totalis (genitiv-/nominativ-formerne). Flere grammatikere i starten af 1800-tallet følger denne opstilling, men Renvall (1815-17) giver den partitive form en ny betegnelse, og akkusativ optræder slet ikke i hans oplistning. I hans 1840-grammatik er dette synspunkt skærpet og begrun-

5 De anvendte forkortelser i eksemplerne er: 1: 1. person; 3: 3. person; GEN: genitiv; NOM: nominativ; PRÆS: præsens; PRÆT: præteritum; SG: singularis. De kasusbetegnelser der fokuseres på i eksemplerne, er skrevet fuldt ud. 
det yderligere: Der er ikke en akkusativkasus når der ikke er noget særskilt mærke. I det følgende halve århundrede følger de fleste grammatikere denne opfattelse. Göran Karlsson (1966) forklarer/forsvarer Renvalls opfattelse med det faktum at den særlige akkusativform på - $t$ på Renvalls tid ikke var udbredt i litteratursproget. Dette var domineret af vestfinsk (uden denne $t$-form), mens $t$-formen var særlig udbredt i østfinsk, der først gradvist i løbet af 1800-tallet făr en større plads i litteratursproget. Fra Setälä (1880) og frem "vender akkusativ tilbage". Han skelner for direkte objekt mellem akkusativ (med de ovennævnte forskellige endelser) og partitiv. Denne opfattelse af akkusativs rolle er vel i dag den mest udbredte, men ikke ubestridt. Den sproghistoriske udvikling har dog medført at der er generel enighed om at regne med en særlig akkusativform for pronominer, jf. (3).

Translativ (nr. 11 i tabel 1), som vi vender tilbage til i 2.2.3., har endelsen -ksi og betegner en tilstand eller en egenskab som resultat af en forudgående proces eller forandring, og kan fx stå som subjektsprædikativ (4) eller objektsprædikativ (5):

$\begin{array}{lll}\begin{array}{l}\text { Lauri } \\ \text { Lauri.NOM } \\ \text { 'Lauri }\end{array} & \begin{array}{l}\text { tul-i } \\ \text { blive-PRÆT.3sG } \\ \text { blev }\end{array} & \begin{array}{l}\text { iloise-ksi } \\ \text { glad-TRANSLATIV } \\ \text { glad' }\end{array} \\ \text { kirjoita-n } & \text { kirja-n } & \text { valmii-ksi } \\ \text { skrive-PRÆs.1sG } & \text { bog-GEN } & \text { færdig-TRANSLATIV } \\ \text { 'jeg skriver } & \text { bogen } & \text { færdig' }\end{array}$

\subsubsection{Renvalls og Rasks kasusanalyser}

I Hovdhaugen et al. (2000: 202) nævnes Renvall som den første der bidrager til en forståelse af det finske kasussystem. Han betragter finske kasus ud fra et typologisk perspektiv, gennemfører en systematisk analyse og udvikler også navngivningen af kasus, første gang i Renvall (1815-1817).

Rask kommer nu til at spille en vigtig rolle i en videre systematisering af Renvalls kasusanalyse, især med hensyn til navngivningen. I Renvalls overleverede svarbrev takker han Rask for i et brev af 14. august 1818 at have sendt nogle nye "kasus-denominationer" og tilføjer at de er bedre end hans egne fra 1815-17. Rask formulerer en artikel om emnet 1818-19, men afsnittet om finsk kasus bliver først publiceret i 1834, to år efter hans død. Rasks bidrag til navngivningen bliver dog allerede publiceret af Renvall 
(1826: XII), hvor Renvall redegør for kasusbetegnelserne og forklarer at det er Rask der har skabt mange af dem. ${ }^{6}$

Vi kan direkte følge Rasks arbejde med kasusbetegnelserne fordi vi kan se hans margenannotationer både til Vhael (1733), se tabel 2, og til Renvall $(1815-17)^{7}$

\begin{tabular}{|l|l|l|l|}
\hline \multicolumn{5}{|l|}{ Tabel 2: Fire navngivninger af finsk kasus i perioden 1733-1840 } \\
\hline Vhael 1733 & $\begin{array}{l}\text { Rask 1819 (eller før): } \\
\text { annotationer til Vhael } \\
\text { 1733: 9-10. }\end{array}$ & Renvall 1815-17 & Renvall 1840 \\
\hline 1. Nominativus & Nom. & Nominativus (1) & Nominativ (1) \\
\hline 2. Genitivus & Poss. & Possessivus (3) & Genitiv (3) \\
\hline 3. Dativus & Allativus & Allativus exterior (5) & Allativ (6) \\
\hline 4. Accusativus & Partialis & Quantitativus (2) & Infinitiv (2) \\
\hline 5. Vocativus & [Vokativ er slettet] & & \\
\hline 6. Ablativus & Elativus & Ablativus exterior (7) & Ablativ (8) \\
\hline 7. Locativus & Inessivus & Locativus interior (8) & Inessiv (11) \\
\hline 8. Mediativus & Adessivus & Locativus exterior (9) & Adessiv (10) \\
\hline 9. Privativus & Ablativus & Ablativus interior (6) & Elativ (9) \\
\hline 10. Negativus & Defectivus & Defectivus (12) & Abessiv (12) \\
\hline 11. Factivus/Mutativus & Factivus & Qualificativus (11) & Factiv (5) \\
\hline 12. Nuncupativus & Qualitativus & Qualitativus (10) & Essiv (4) \\
\hline 13. Penetrativus & Illativus & Allativus interior (4) & Illativ (7) \\
\hline 14. Instructivus & - & Adverbialis (14) & Adverbialis (14) \\
\hline & & Suffixivus (13) & Suffixiv (13) \\
\cline { 2 - 4 } & (Suffixiv(us) 'komitativ' (note 3)) \\
\hline
\end{tabular}

Ud af Vhaels 14 kasus ser Rask bort fra vokativ (der ikke findes som selvstændig form i finsk) og vælger også at udelade instruktiv med begrundelsen at det er en meget sjælden form og stort set kun findes i faste udtryk. Tilbage er så 12 former der umiddelbart passer fint i en opstilling på 4x3, som følger: ${ }^{8}$

6 Se også Rask (1832: 34, note 4).

7 I de to Renvall-opstillinger er i parentes markeret i hvilken rækkefølge Renvall selv oplister kasus.

8 Skemaet fra Rask (skrevet ca. 1819 [1834] 1932-33: 258-59) er udarbejdet fælles for finsk og en række beslægtede nabosprog, men Rask har andetsteds udtrykt at det passer bedst på finsk. Jeg har med markeringen (1832) indført tre Rask-betegnelser fra Rask (1832). De er interessante her da de svarer til Hjemslevs franske termer.

Vedrørende de 12 finske kasusformer i skemaet har Rask en række henvisninger til latinske kasus, samt eksempler fra latin og dansk. Jeg bringer kun dette materiale for Nævneform, Deleform og Bliveform: Her har det betydning for Hjelmslevs gengivelse af skemaet (se 3.1. og 3.5.). rex creatus est $=$ han blev valgt til konge; creaverunt (eum) regem $=$ de valgte $($ ham $)$ til konge. 


\begin{tabular}{|c|c|c|c|c|}
\hline \multicolumn{5}{|c|}{$\begin{array}{l}\text { Tabel 3: Rasks opstilling af finsk kasus, skrevet ca. 1819, publiceret posthumt } 1834 \\
\text { (suppleret med tredelingen “Nærmelse, Hvile, Fjærnelse" fra Rask (1832) }\end{array}$} \\
\hline $\begin{array}{l}\text { Begyndelse } \\
(1819 \text { [1834]) } \\
\text { Nærmelse (1832) }\end{array}$ & $\begin{array}{l}\text { Nævneform } \\
\text { definitivus } \\
\text { (nom., acc.) } \\
\text { fx Kongen }\end{array}$ & $\begin{array}{l}\text { Bliveform } \\
\text { effectivus } \\
\text { (nom., acc.) } \\
\text { fx rex creatus est, } \\
\text { creaverunt (eum) } \\
\text { regem (se note 8) }\end{array}$ & $\begin{array}{l}\text { Til-form } \\
\text { allativus }\end{array}$ & $\begin{array}{l}\text { Indi-form } \\
\text { illativus }\end{array}$ \\
\hline $\begin{array}{l}\text { Hvile / Væren } \\
\text { (1819 [1834]) } \\
\text { Hvile (1832) }\end{array}$ & $\begin{array}{l}\text { Ejeform } \\
\text { possessivus }\end{array}$ & $\begin{array}{l}\text { Væreform } \\
\text { prcedicativus }\end{array}$ & $\begin{array}{l}\text { Ved-form } \\
\text { adessivus }\end{array}$ & $\begin{array}{l}\text { Udi-form } \\
\text { inessivus }\end{array}$ \\
\hline $\begin{array}{l}\text { Ophør } \\
(1819 \text { [1834]) } \\
\text { Fjærnelse (1832) }\end{array}$ & $\begin{array}{l}\text { Deleform } \\
\text { infinitivus } \\
\text { (nom., acc.) } \\
\text { fx Konge } \\
\text { (udtrykker den } \\
\text { franske } \\
\text { delingsartikel) }\end{array}$ & $\begin{array}{l}\text { Mangleform } \\
\text { defectivus }\end{array}$ & $\begin{array}{l}\text { Fra-form } \\
\text { ablativus }\end{array}$ & $\begin{array}{l}\text { Udaf-form } \\
\text { elativus }\end{array}$ \\
\hline
\end{tabular}

Nogle kommentarer til skemaet:

a) Rasks glansnummer er først og fremmest de to kolonner til højre, som han får opstillet og navngivet på systematisk vis. Rasks navngivning af disse 6 lokalkasus er stadig den gængse i finsk kasusgrammatik (se fx F. Karlsson 2000).

b) Alle de danske og latinske kasusnavne er Rasks valg da der ikke var nogen veletableret terminologi. En del af de latinske kan føres tilbage til Vhael (1733) og/eller Renvall (1815-17) (se tabel 2). Alle 6 betegnelser i de to lokalkasussøjler bliver enten udarbejdet af Rask eller originalt anvendt af ham.

c) Skemaet viser hvordan Rask konstruerer sit navngivningssystem ved systematisk brug af de latinske præpositioners betydning: in-essiv, in-lativ (illativ), ad-essiv, ad-lativ (allativ), ab-lativ, e(x)-lativ.

d) Rask (1832: 33-35 med finske eksempler) forklarer selv at hans kasusoversigt først opbygges via de 6 lokalkasus, lodret organiseret efter nærmelse (6), hvile (7), fjernelse (8). Dette fremgår også fint af Rasks danske kasusbetegnelser i disse to kolonner, her illustreret med mine eksempler til 4. kolonne:

$\begin{array}{lll}\text { koira } & \text { juoks-i } & \text { talo-on } \\ \text { hund.NOM } & \text { løbe-PRÆT.3sG } & \text { hus-ILLATIV } \\ \text { 'hunden } & \text { løb } & \text { ind i huset' }\end{array}$


(7)

$(8)$

$\begin{array}{lll}\begin{array}{l}\text { koira } \\ \text { hund.NOM } \\ \text { 'hunden }\end{array} & \begin{array}{l}\text { oli } \\ \text { være.PRÆT.3sG } \\ \text { var }\end{array} & \begin{array}{l}\text { talo-ssa } \\ \text { hus-INESSIV } \\ \text { inde i huset' }\end{array} \\ \text { koira } & \text { juoks-i } & \text { talo-sta } \\ \text { hund.NOM } & \text { løbe-PRÆT.3sG } & \text { hus-ELATIV } \\ \text { 'hunden } & \text { løb } & \text { ud af huset' }\end{array}$

"Efter disse [to kolonner til højre] ordnes de mere afsondrede, der ligeledes ere af en dobbelt Art, tre dunklere [1. kolonne her] og tre tydeligere og mere overensstemmende med Stedsbestemmelserne" (Rask 1832: 34). Han har ingen specifik forklaring på rækkefølgen i første kolonne.

e) I de to kolonner til venstre optræder parret nom. acc. tre gange. Rask kommenterer at ingen af de finske kasus "svarer egentlig til nominativus eller accusativus i Latinen, da her slet ikke tænkes paa de subjektive og objektive Forhold, som udgjör Inddelingsgrunden i alle sarmatiske [indoeuropæiske] Sprog, saa at man strax her ser sig ligesom i en anden Verden, hvor der tænkes paa en aldeles grundforskjellig Maade" (Rask 1819 [1834] 1932-33: 258-259).

Ved Nævneform og Deleform er der ingen problemer med at udlede hvilke finske kasusformer Rask faktisk refererer til, nemlig dem der i gængse fremstillinger i dag kaldes nominativ og partitiv. Derimod er det ikke entydigt ud fra Rasks skema hvilken finsk kasusform hans Bliveform refererer til. Hvis man inddrager hans annotationer til Vhael, synes det dog oplagt at det er Vhaels (og Renvalls) 'factiv' som Rask refererer til, idet han oversætter den med 'Forandrings-form' (i sine annotationer til Vhael 1733: 6). 'Factiv' svarer til det der i dag normalt kaldes translativ. Denne fortolkning bestyrkes af Rask (1832: 34), hvor han bringer eksemplet tuoli-ksi ved Bliveform. Dette er netop translativformen af det finske ord for 'stol' (se også (4) og (5) i 2.2.2). Denne fortolkning af Rasks skema betyder at akkusativ ikke har sit eget rum i Rasks skema, svarende til at det ikke er helt entydigt at regne med en særlig form til finsk akkusativ (jf. 2.2.2.). Direkte objekt for substantiver udtrykkes ved nominativ-, genitiv- og partitivformer; Rask får delvist dette frem i skemaet via 'acc.' ved Nævneform og Deleform. Bliveformen, altså translativ, kan som nævnt (2.2.2.) bruges til såvel subjekts- som objektsprædikativ; at Rask udover 'nom.' har et 'acc.' i dette felt giver derfor mening. Disse forhold vedrørende akkusativ får betydning ved Hjelmslevs gengivelse af Rasks skema (se 3.5.). 
Rasks betegnelser for de seks lokalkasus til højre i skemaet blev indført i den finske grammatiktradition via Renvalls ordbog (1826) og grammatik (1840) (jf. tabel 2).

\section{Hjelmslevs brug af Rask}

\subsection{Hjelmslevs gengivelse af Rasks skema}

Rasks samlede skema får en ny anvendelse da Hjelmslev (1935: 64) inddrager det i sin La catégorie des cas 1 . Hos Hjelmslev ser skemaet således ud (han bringer kun forkortelserne for de gængse kasusnavne, i tabel 4 har jeg udskrevet dem i parentes):

\begin{tabular}{|c|c|c|c|c|}
\hline \multicolumn{5}{|c|}{ Tabel 4: Hjelmslevs gengivelse af Rasks kasusskema (Hjelmslev 1935: 64) } \\
\hline $\begin{array}{c}\text { Relation } \\
+ \\
\begin{array}{c}\text { (rapprochement) } \\
\text { [nærmelse] }\end{array}\end{array}$ & $\begin{array}{c}\mathrm{N} \\
\text { (nominativ) }\end{array}$ & $\begin{array}{c}\mathrm{II} \\
\text { Ac } \\
\text { (akkusativ) }\end{array}$ & $\begin{array}{c}\mathrm{Al} \\
\text { (allativ) }\end{array}$ & $\begin{array}{c}\mathrm{Il} \\
\text { (illativ) }\end{array}$ \\
\hline $\begin{array}{c}\text { (repos) } \\
{[\text { hvile] }}\end{array}$ & $\begin{array}{c}\mathrm{G} \\
\text { (genitiv) }\end{array}$ & $\begin{array}{c}\text { Es } \\
\text { (essiv) }\end{array}$ & $\begin{array}{c}\text { Ads } \\
\text { (adessiv) }\end{array}$ & $\begin{array}{c}\text { Ine } \\
\text { (inessiv) }\end{array}$ \\
\hline $\begin{array}{c}\text { (éloignement) } \\
\text { fjernelse] }\end{array}$ & $\begin{array}{c}\mathrm{Pt} \\
\text { (partitiv) }\end{array}$ & $\begin{array}{c}\text { Abs } \\
\text { (abessiv) }\end{array}$ & $\begin{array}{c}\text { Ab } \\
\text { (ablativ) }\end{array}$ & $\begin{array}{c}\mathrm{E} \\
\text { (elativ) }\end{array}$ \\
\hline
\end{tabular}

Hjelmslev gengiver Rasks kasusindplaceringer, blot med moderniserede navne. Dog er der problemet i felt II+. Som argumenteret ovenfor har Rask efter al sandsynlighed tænkt på den kasus der i dag kaldes 'translativ', og 'acc.' i Rasks felt her (jf. tabel 3) er en henvisning til brugen af akkusativ i latin ved objektsprædikativ. Hjelmslev havde jo netop udgivet Rasks værker, så ændringen hos Hjelmslev, nemlig at han her indplacerer en finsk akkusativ, er bemærkelsesværdig og bliver diskuteret i 3.5.

Rask (1832: 33-34) taler ved lodret læsning af skemaet om "en Nærmelse, en Hvile, en Fjærnelse", en tredeling der er helt parallel til Hjelmslevs betegnelser, jf. (6), (7) og (8) ovenfor. Rask har ikke entydigt et overbegreb for den vandrette dimension; Hjelmslev siger at der bliver en større grad af intimitet (degré d'intimité) når man går fra I mod IV. De kasus der er i kolonne IV, udtrykker et tættere/mere intimt forhold mellem de to implicerede objekter end naboen i III. Rask har udtrykt Hjelmslevs generelle pointe via sine danske betegnelser i tabel 3. 'Ind-i-formen' (illativus) (9) 
udtrykker en tættere relation end 'til-formen' (allativus) (10), hvilket så også kan overføres på det skema Hjelmslev bringer:

$\begin{array}{lll}\text { lintu } & \text { lentä-ä } & \text { talo-on } \\ \text { fugl.NOM } & \text { flyve-PRÆs.3sG } & \text { hus-ILLATIV } \\ \text { 'fuglen } & \text { flyver } & \text { ind i huset' }\end{array}$

(10)

$\begin{array}{lll}\text { lintu } & \text { lentä-ä } & \text { kato-lle } \\ \text { fugl.NOM } & \text { flyve-PRÆS.3sG } & \text { tag-ALLATIV } \\ \text { 'fuglen } & \text { flyver } & \text { op på taget' }\end{array}$

De to første søjler står mere uforklarede hen hos Hjelmslev. Det er også vigtigt at huske at Hjelmslev eksplicit tager forbehold over for detaljerne $\mathrm{i}$ Rasks analyse (og at han, uden at nævne det, har ændret lidt i opstillingen).

\subsection{Formålet med Hjelmslevs kasusbog}

Hjelmslev gav i 1933 i Lingvistkredsen en meddelelse om kasus. I samme periode forelæste han over samme emne som privatdocent. ${ }^{9}$ I $1935 \mathrm{blev}$ det til bogen La Catégorie des cas. Etude de grammaire générale 1, tænkt som en demonstration af de almene principper fra hans bog fra 1928, Principes de grammaire générale. I kasusbogen bruger Hjelmslev for forste gang betegnelsen "immanent metode" om en beskrivelse der kun tager hensyn til de forskelle der er sprogligt givne. Han tager således afstand fra at definere kategorien kasus ved inddragelse af de aristoteliske begreber subjekt, objekt og prædikat da de ikke afspejler sig direkte i den sproglige form (Hjelmslev 1935: 50). Hjelmslevs beskrivelse er primært semantisk. Han bestemmer selve kategorien kasus som udtrykkende et forhold mellem to objekter (Hjelmslev 1935: 96) (hvorved vokativ udelukkes som kasus, mens ordstilling og adverbialformer til gengæld medtages) og bygger på en rumligt orienteret lokalistisk teori med retning som grundbegreb (se også 3.2.). Det originale ligger $i$ at kasusbegreberne ikke blot bestemmes efter deres indhold, men også efter deres omfang (ekstensiv eller vag betydning over for intensiv eller præcis betydning), idet de sproglige modsætninger siges at være participative, fx mellem A på den ene side og A+ikke-A på den anden. Af pladshensyn går jeg ikke her videre ind på participationslovene. Hjelmslev understreger at når man vil undersøge en kategori som

9 Det følgende er delvist inspireret af Togeby (1966). 
kasus, så er det vigtigt at tage udgangspunkt i sprog hvor denne kategori er stærkt udviklet (Hjelmslev 1935: 83). Derfor er fx finsk og ungarsk bedre udgangspunkter end de indoeuropæiske sprog.

\subsection{Hjelmslevs lokalistiske kasusteori}

Hjelmslev (1935: 36f.) tager udgangspunkt i Bopp-eleven Wüllners lokalistiske kasusteori, der i Hjelmslevs gengivelse indebærer tre grundlæggende principper: 1) at det fænomen som det lingvistiske tegn udpeger, er af subjektiv, ikke objektiv, natur; det talende subjekt vælger ikke grammatiske former ud fra objektive forhold, men ud fra sin anskuelse/idé vedrørende disse forhold, 2) at den anskuelse/idé man skal søge i en sproglig form, er én idé, én grundbetydning (Grundbedeutung) på et abstraktionsniveau der giver mulighed for at udlede alle konkrete anvendelser, 3) at lingvistikkens metode skal være empirisk, ikke apriorisk.

Mere specifikt vedrørende kasus overtager Hjelmslev Wüllners tanke at det subjektive fænomen der betegnes af kasus, er en rumlig anskuelse (conception spatiale, Raumanschauung), der appliceres på forskellige objektive fænomener vedrørende rum, tid, logisk kausalitet eller syntagmatisk styring. Lokalisterne har opstillet basis for en kohærent kasusteori som består i at se den abstrakte idé om retning (direction) som den væsentlige og primære dimension for kasus. Den indebærer en opdeling i rapprochement, repos, éloignement (jf. tabel 4). Hvis vi kalder rapprochement for + , så kan man via en matematisk-logisk tilgang få seks muligheder: +, -, 0, +/-, +/(-), (+)/- (positif, négatif, neutre, complexe, complexe-positif, complexe-négatif) (Hjelmslev 1935: 38-39, 98). Lokalisterne kan derfor et langt stykke af vejen redegøre for indoeuropæiske kasusforhold hvor antallet af kasus er begrænset til 6 eller derunder. Selv om Hjelmslev ikke arbejder med en matematisk-logisk tilgang, men med participationsrelationer, når også han i bogen frem til et maksimum på 6 kasus pr. dimension.

Hvis man skal redegøre for større kasussystemer, er der brug for flere dimensioner. Hjelmslev (1935: 26) refererer Doeleke for at have introduceret et todimensionelt system der indeholder både en lokalistisk relation mellem genitiv, ablativ og dativ og en syntagmatisk relation mellem nominativ (déterminant, rectus) og akkusativ (déterminé, oblique). Denne anden dimension bør imidlertid ifølge Hjelmslev (1935: 95-96) defineres via en rumlig dimension, ikke via styringsforhold, indépendance/dépendance, som man ofte har gjort fra antikken og frem; ifølge Hjelmslev hører disse styringsforhold ind under 1.-dimensionens generelle begreb: direction. 


\subsection{Rasks finske kasusskemas rolle i Hjelmslevs kasusbog}

Det er i forhold til disse overvejelser at Hjelmslev bringer Rasks skema over finsk kasus i spil. I første omgang introduceres skemaet i et historisk delafsnit om pankroniske teorier som et alternativ til kasusteorier knyttet til udviklingen af den indoeuropæiske sprogvidenskab. Hjelmslev påpeger i sin kommentar til skemaet at selv i et så lokalistisk kasussystem som det finske er der ingen 'rene' lokalkasus; de bruges alle også til syntagmatiske forhold, fx kan den finske lokalkasus allativ opfylde funktionen som dativobjekt (Hjelmslev 1935: 64-68), jf. mit eks.:

$\begin{array}{lll}\text { annan } & \text { kirjan } & \text { opettaja-lle } \\ \text { give-PRÆS.1SG } & \text { bog-GEN } & \text { lærer-ALLATIV } \\ \text { 'jeg giver } & \text { bogen } & \text { til læreren' }\end{array}$

Hjelmslevs formål med at bringe skemaet er dog først og fremmest at introducere en 2.-dimension der er rumligt defineret. Ud fra en fortolkning af Rasks konkrete angivelser i dette skema, primært søjle III og IV med de seks lokalkasus (Hjelmslev 1935: 65), betegner Hjelmslev i første omgang 2.-dimensionen som graden af intimitet.

I opsamlingen af bogens historiske afsnit vender Hjelmslev tilbage til problematikken (Hjelmslev 1935: 95ff), og her bliver Rask-skemaet fremstillet som 'prototypen' på en 2.-dimension. Rask-skemaets centrale placering understreges af at Hjelmslev umiddelbart efter bringer sin generelle definition af kategorien kasus.

Da Hjelmslev (1935: 127ff.) opstiller et sublogisk system for kasus, optræder Rasks skema igen i en central rolle. Her specificerer Hjelmslev sin 2.-dimension, tager udgangspunkt i Rasks skema, generaliserer det og ændrer betegnelsen graden af 'intimitet' til det mere abstrakte: graden af 'kohærens/inkohærens' (fx udtrykker dansk 'på' i 'på bordet' kohærens, mens 'over' i 'over bordet' udtrykker inkohærens). Siden indfører Hjelmslev en 3.-dimension: subjektivitet - objektivitet, der tager udgangspunkt i forskellen mellem 'foran'/'bagved' på den subjektive side, og 'over'/'under' på den objektive side. Hjelmslev påpeger at alle tre dimensioner tager udgangspunkt i anskuelser vedrørende rumlige forhold. Ud fra disse tre dimensioner udarbejder han så skemaer for først tredimensionelle og siden todimensionelle kasussystemer.

Sammenfattende kan det siges, at Rasks kasusskema spiller en vigtig rolle i Hjelmslevs fremstilling, først og fremmest som eneste inspiration til en rumligt defineret 2. dimension, i samklang med den første retnings- 
dimension. Introduktionen af det finske kasusskema er tillige udtryk for Hjelmslevs ønske om at udvikle en kasusteori der rækker ud over de relativt kasusfattige indoeuropæiske sprog.

\subsection{Ohrts kritik}

Ohrt efterlyser i sit brev (se s.1) en translativ i skemaet (tabel 4). Her er vi tilbage ved forbindelsen til Hjelmslevs fortolkning af Rasks Bliveform (felt II+). Rask angiver at den indeholder nogle elementer der svarer til latinsk nominativ og akkusativ, nemlig subjekts- og objektsprædikativ. Som argumenteret ovenfor, er det temmelig sikkert at Rask her tænker på translativ. Man kan så kun gisne om hvorfor Hjelmslev vælger at skrive akkusativ.

En mulighed er at det er vigtigt for Hjelmslev at have akkusativ med i skemaet for at det kan blive generaliserbart ved sammenligninger med $\mathrm{fx}$ indoeuropæiske sprog.

Hjelmslevs indplacering af akkusativ kan også være et resultat af at han bliver fanget lidt på det forkerte ben af sprogudviklingen i finsk når han ikke bringer et skema i eget navn men vil benytte Rasks skema i sin generelle argumentation. Som nævnt i 2.2.2. har finske substantiver ikke en særlig akkusativform, men en gruppe pronominer har. Dette har siden slutningen af 1800-tallet været et morfologisk argument for at anerkende en akkusativkasus. Det var derimod ikke noget stærkt argument på Renvall og Rasks tid da disse former på daværende tidspunkt endnu ikke var særlig udbredte i litteratursproget, så Rask havde ingen finsk akkusativ, men en translativ i det pågældende felt. Enten må Hjelmslev bevare Rask rent (altså med translativ, men uden akkusativ) og dermed bringe et skema der er ude af trit med sprogudviklingen og hans egen samtids grammatikere; eller han må "justere" lidt på Rask og indføre akkusativ i skemaet og dermed på dette punkt få skemaet mere i samklang med situationen i 1900-tallet, men med det resultat at translativ forsvinder.

Translativ udtrykker ofte noget med at "blive til", fx som i (12):

$$
\begin{array}{lll}
\text { tyttö } & \text { aiko-o } & \text { insinöör-ksi } \\
\text { pige.NOM } & \text { agte-PRÆS.3SG } & \text { ingeniør-TRANSLATIV } \\
\text { 'pigen } & \text { tænker på (agter) } & \text { at blive ingeniør' }
\end{array}
$$

Translativ ville derfor, som Ohrt i sit brev antyder, passe pænt med Hjelmslevs overordnede idé om at første række er en "nærme sig til"-kasus, og hvis man flyttede "deleform" (partitiv) over i bunden af II-kolonne, så ville 
man få en II-kolonne der svarer til et tidligere sproghistorisk trin, ${ }^{10}$ nemlig (fra neden af): partitiv - essiv - translativ; som nævnt i 2.2.2. var partitivs oprindelige hovedfunktion at være separativ-kasus. Hjelmslev har jo helt fået fjernet translativ. Rask er derimod i overensstemmelse med Ohrt med hensyn til indplaceringen af translativ, men Rask vælger ikke at følge Ohrt i dennes sproghistorisk baserede indplacering af partitiv. Rask placerer partitiven i søjle med nominativ (og genitiv), og han har muligvis en god (synkron) pointe ved at placere dem som to yderpoler i den "dunkle" søjle med de mindst lokalistiske kasus. Som Fred Karlsson (2000: 86) skriver: "Nominativ och partitiv kan betraktas som varandras motsatser. Båda kan användas vid ord som i satsen fungerar som subjekt, objekt och predikativ, varvid det gäller att välja rätt mellan dem" (for valg af kasus ved direkte objekt, se 2.2.2.).

Ohrt problematiserer indplaceringen af abessiv og gør i sit brev også opmærksom på at Hjelmslev ser bort fra et par kasus som ofte regnes med til systemet, bl.a. instruktiv og komitativ.

Hjelmslev svarer Ohrt at han allerede i 1933 havde fremlagt sin egen kasusopfattelse vedrørende finsk, herunder de nævnte former fra Ohrts brev. I Hjelmslevs arkiv findes flere skitseagtige skemaer vedrørende finsk kasus, typisk med 16 felter, men disse noter ligger ikke med en velorganiseret og veldateret sammenhæng, så det er ikke enkelt at udlede "Hjelmslevs analyse", og det er muligt at han heller ikke selv følte sig færdig med den. Hverken vedrørende latin eller finsk fik Hjelmslev publiceret sin egen kasusfremstilling, selv om begge sprog havde en fremtrædende placering i hans kasusanalyse. Hjelmslev (1935) har teoretisk brug for de to dimensioner man kan finde i Rasks skema som jo i princippet var færdigudviklet (i al fald publiceret). Det kan meget vel være en grund til at Hjelmslev har valgt at bringe skemaet som "Rasks skema". Som nævnt tidligere garderer Hjelmslev sig lidt ved at sige at detaljerne i skemaet står til diskussion.

Jeg bringer neden for et eksempel på et kasusskema udarbejdet af Hjelmslev selv, sandsynligvis før bogens udgivelse. Der er i arkivet ingen kommentarer direkte knyttet til skemaet, så mit formål her er ikke at gå

10 Jf. Hakulinen (1961: 69-71). 
dybere ind i Hjelmslevs analyse, men forst og fremmest at dokumentere at Hjelmslev faktisk havde udarbejdet skitser af egne analyser af det finske kasussystem: ${ }^{11}$

\begin{tabular}{|c|c|c|c|c|c|}
\hline \multicolumn{6}{|c|}{ Inhærens ("lokalisering") } \\
\hline \multirow{5}{*}{$\begin{array}{l}\text { Kausalitet } \\
\text { ("retning") }\end{array}$} & & + & $+/-$ & 0 & - \\
\hline & + & illativ & komitativ & translativ & allativ \\
\hline & $+/-$ & inessiv & instruktiv & essiv & adessiv \\
\hline & 0 & akkusativ & adverbialis & nominativ & genitiv \\
\hline & - & elativ & abessiv & partitiv & ablativ \\
\hline
\end{tabular}

Som det ses, er Hjelmslev i skemaet på linje med Ohrt vedrørende indplaceringen af partitiv sammen med translativ og essiv, vedrørende inddragelse af de manglende kasus, og med hensyn til at flytte abessiv væk fra "translativ"-kolonnen.

\section{Konklusion}

Rask navngiver og systematiserer de seks lokalkasus i finsk på en klarere måde end alle sine forgængere, og dette resultat er via Renvalls efterfølgende værker blevet stående i forskningen i finsk kasus. Som redaktør af Rasks værker og breve havde Hjelmslev et førstehåndskendskab til disse forhold.

Hjelmslev kan bruge Rasks opstilling af de seks lokalkasus til at indføre en 2.-dimension i sin rumligt lokaliseringsorienterede systematisering af kasus. Hjelmslevs interesse for finsk kasus og Rasks behandling af samme har sikkert også været en ganske vigtig faktor for Hjelmslev i hans bestræbelse på at frigøre sig fra de kasusteorier der var bundet til de relativt kasusfattige indoeuropæiske sprog. Godt nok ønsker Hjelmslev en grammaire générale, men det er sprogbygningernes særpræg og store forskellighed der er det centrale udgangspunkt; og han føler sig nok meget på linje med Rask når denne fremhæver at de finsk-ugriske sprog afspejler en helt anden tilgang end de indoeuropæiske.

11 Inhærens er en underkategori af kohærens (3.4.) og går på graden af intern relation sammenlignet med ekstern relation (Hjelmslev 1935: 129-30). Det giver således god mening at illativ (Ind-i-kasus hos Rask) er mere inhærent end allativ (Til-kasus hos Rask). Hvordan de to andre søjler er blevet indplaceret, fremgår ikke umiddelbart. Som nævnt findes der også andre versioner i Hjelmslevs arkiv. 
Ohrts kritikpunkter af det skema som Hjelmslev bringer i sin bog, er meget relevante, og noget af kritikken skyldes Hjelmslev selv, nemlig hans udskiftning af Rasks translativ med en akkusativ. De nævnte kritikpunkter er ikke relevante i forhold Hjelmslevs egen analyse sådan som den antydes i tabel 5 .

\section{Om forfatteren}

Viggo Bank Jensen, postdoc, Institut for Nordiske Studier og Sprogvidenskab (NorS), Københavns Universitet.

\section{Litteratur}

Doeleke, W.H. (1814): Versuche philosophisch-grammatischer Bemerkungen. Zweiter Versuch. Leipzig: Johann Ambrosius Barth.

Hakulinen, L (1961): The Structure and Development of the Finnish Language. The Hague: Indiana University and Mouton \& Co.

Hjelmslev, L. (1935): La catégorie des cas, 1. I: Acta futlandica VII, 1.

Hjelmslev-Arkivet, Det Kongelige Bibliotek, Acc. 1992/5. Se også hjemmesiden:

https://cc.au.dk/en/infrastructuralism/about-project-infrastructuralism/ Hovdhaugen, E., F. Karlsson, C. Henriksen \& B. Sigurd. (2000): The History of Linguistics in the Nordic Countries. Jyväskylä: Societas Scientarium Fennica. Jespersen, O. (1937): Analytic Syntax. Copenhagen: Levin \& Munksgaard. Karlsson, F. (2000): Finsk Grammatik. 7.oplag. Helsinki: Suomalaisen Kirjallisuuden Seura.

Karlsson, G. (1966): 'Akkusatiivi' suomen kielopin terminä (tysk abstract: 'Akkusativ' als Fachausdruck der finnischen Grammatik). I: Virittää̈ 70, 16-28.

Rask, R. (1818): Undersøgelse om det gamle Nordiske eller Islandske Sprogs Oprindelse. København. Gyldendalske boghandlings forlag.

Rask, R. (Skrevet ca. 1819 [1834] 1932-33): En Afhandling om Sprogkyndigheden (Lingvistikken), især de finniske Folkeslags Inddeling. I: Udvalgte Afhandlinger II. L. Hjelmslev (red.). København: Levin \& Munksgaard, 239-283.

Rask, R. (1832): Resonneret lappisk Sproglere. København: Schubothes Boghandling.

Renvall, G. (1815-17): De signis relationum nominalium in Lingua Fennica. I-VIII. Aboæ: Frenckell. 